\title{
Risk Level Based Management System: A Control Banding Model for Occupational Health and Safety Risk Management in a Highly Regulated Environment
}

\author{
David M. ZALK ${ }^{*}$, Ryan KAMERZELL ${ }^{1}$, Samuel PAIK ${ }^{1}$, \\ Jennifer KAPP ${ }^{1}$, Diana HARRINGTON ${ }^{2}$ and Paul SWUSTE ${ }^{3}$ \\ ${ }^{1}$ Lawrence Livermore National Laboratory, P.O. Box 808, L-871, Livermore, CA 94551, USA \\ ${ }^{2}$ Consolidated Safety Services, NASA, Ames Research Center, Moffett Field, CA 94035, USA \\ ${ }^{3}$ Delft University of Technology, Safety Science Group, P.O. Box 5015, NL-2600 GA Delft, The Netherlands
}

Received February 11, 2009 and accepted June 19, 2009

\begin{abstract}
The Risk Level Based Management System (RLBMS) is an occupational risk management (ORM) model that focuses occupational safety, hygiene, and health (OSHH) resources on the highest risk procedures at work. This article demonstrates the model's simplicity through an implementation within a heavily regulated research institution. The model utilizes control banding strategies with a stratification of four risk levels (RLs) for many commonly performed maintenance and support activities, characterizing risk consistently for comparable tasks. RLBMS creates an auditable tracking of activities, maximizes OSHH professional field time, and standardizes documentation and control commensurate to a given task's RL. Validation of RLs and their exposure control effectiveness is collected in a traditional quantitative collection regime for regulatory auditing. However, qualitative risk assessment methods are also used within this validation process. Participatory approaches are used throughout the RLBMS process. Workers are involved in all phases of building, maintaining, and improving this model. This worker participation also improves the implementation of established controls.
\end{abstract}

Key words: Control banding, Qualitative risk assessment, Occupational risk management, Occupational health and safety management system, Risk level approach, Toolbox, Participatory

\section{Introduction}

Lawrence Livermore National Laboratory (LLNL) is a Department and Energy (DOE) and National Nuclear Security Administration (NNSA) research and development (R\&D) facility that is operated by the Lawrence Livermore National Security (LLNS) LLC. What makes LLNL unique from a majority of organizations with over 6,000 employees is its primary R\&D focus, rather than a traditional production or manufacturing working environment. Most large-scale enterprises worldwide with ORM models within occupational health and safety management systems (OHSMS) are focused on a finite number of uniform activities.

*To whom correspondence should be addressed. E-mail: zalk1@1lnl.gov
LLNL's R\&D focus breaks away from traditional systems by consistently performing unique work. Therefore, the creation of new and potentially hazardous operations and related occupational exposures is standard. Perhaps an expected outcome of this large-scale R\&D work is a pervasive regulatory oversight. Though based in California, the California Occupational Safety and Health Administration (OSHA) does not oversee LLNL's activities. Instead, Federal OSHA (FedOSHA) has jurisdiction. In addition, as LLNL is run by LLNS for the DOE, additional contractual requirements are in place to ensure workers performing the tasks that benefit national $R \& D$ are well protected. For industrial hygiene $(\mathrm{IH})$, the contract requires the lowest established occupational exposure limit (OEL) for a given chemical, physical, or biological exposure. Therefore, the ACGIH ${ }^{\circledR}$ Threshold Limit Values (TLVs) often meet this specification and therefore 
are treated as regulation. DOE has also developed and enforced standards published in the Code of Federal Regulations for LLNL compliance. To say that LLNL has substantial regulatory oversight is a quintessential understatement.

As an outcome of this regulatory oversight, LLNL has a consistent stream of auditors, both internal and external, offering subject matter expertise on the quality of adherence to requirements. A common by-product of this process is a steady stream of policy implementation and deadlines. To the Environmental Safety and Health $(\mathrm{ES} \& \mathrm{H})$ multidisciplinary teams assisting clientele in working safely, this regulatory oversight process is often seen as a steady stream of increasing paperwork. Therefore, this escalating paperwork often reduces team member opportunities to get into a field practitioner mode. It is within this working environment that the RLBMS concept was born.

\section{Methods}

\section{Building the RLBMS; managing risk}

Although ORM is seen as responsible for reducing injury and illness statistics, the quality of occupational risk perspective should be the primary consideration ${ }^{1)}$. Numerous OHSMSs are available for managerial use and implementation relating to occupational, safety, hygiene, and health $(\mathrm{OSHH})$ professions. Since their growth in the 1990s, they continue to gain importance in measuring performance and OSHH management success ${ }^{2}$. The three main components of an OHSMS common worldwide are establishing input parameters, risk assessment and control, and management and evaluation ${ }^{2-6)}$. Taken together, they comprise an ORM basis for fundamental and comprehensive OSHH regulatory adherence. However, not all OHSMSs are equal as some measure managerial systems whereas others emphasize the work environment where implemented ${ }^{6}$.

ORM programs focusing on risk factors are considered the most essential approach for reducing the economic and sociological burden of work-related illness and injury ${ }^{7)}$. Programs that manage risk appropriately balance all aspects of risk affecting a company's operation. Thus, risk is often defined beyond its occupational application, to include economic viability and product quality riskbenefit analyses. These OHSMS approaches are riskbased; however, the risk is not necessarily a graded management decision making so much as competing risk factors. Here, risk-based solutions are in a decision-making and problem-solving context seeking cost effectiveness. Review of ORM principles and national OHSMS approaches reveals worker-based success and measurable reduction of occupational risk factors are often seen when internal, adaptive risk assessment procedures and controls are developed ${ }^{6}$. Multidisciplinary research also finds that emphasizing individual task-based controls by risk, rather than on control technology, achieves effective ORM across the OSHH professions ${ }^{8)}$.

\section{Banding risk}

In recent years a qualitative occupational risk assessment strategy known as control banding (CB) has gained international attention in its goal of offering a complementary and simplified approach to reduce work-related injury and illness ${ }^{9)}$. CB's simplified approach to grouping workplace hazards into stratified risk "bands" based on common hazards and commensurate control approaches offers long-sought unification across OSHH professions ${ }^{10)}$. The term has an IH focus and represents a qualitative instrument to assess risks for chemical substances, generating solutions and implementing control measures ${ }^{11)}$. However, the concept of segregating risk into a simple and discreet order has its roots in occupational safety. A number of qualitative safety risk concepts began in the 1970's focusing on stratification, or banding, of central events in a risk matrix describing the likelihood and severity of an explosion, or toxic material release, for use by major chemical companies. In the 1980's this risk assessment approach expanded to radiation, lasers, biosafety, and eventually pharmaceuticals in the 1990's ${ }^{9,12,13)}$. Modern CB approaches utilize simplified strategies directing users to control solutions and control guidance sheets for chemical exposure, or seeking specialist advice for the highest risks ${ }^{9}$.

Recent CB expansion of range, beyond bulk chemicals and into OSHH professions, uses the basic stratification of practical prevention strategies as earlier risk matrices. This includes barrier banding, a strategy utilizing CB concepts for occupational safety rather than $\mathrm{IH}^{14)}$. Barrier banding explores the practicality of addressing safety accident scenarios, implementing barriers, and managing solutions in a simplified manner to achieve injury reduction $^{15)}$. CB in ergonomics offers comparable approaches for controlling musculoskeletal disorders within participatory programs ${ }^{16,17)}$. Commonality of form and function, toward identifying and reducing OSHH risks and controlling and reducing injuries and illnesses, has built international demand for simplified approaches to banding risk ${ }^{10)}$.

\section{Risk level approach}

Safety sciences have few qualitative tools to assess risks ${ }^{18)}$. Risk is seen as a numeric variable, as its most simple format equates the combination of unwanted consequences and the probability for their occurrence. Probabilities and consequences are normally divided into 
groups or classes and provided with a value. By multiplying these values, a risk score is created and used to compare different risks. Because valuing probabilities can be difficult, variations are present which split these probabilities. First a hazard exposure frequency is estimated, then the probability of scenarios occurring is specified for consequences ${ }^{19}$ ). Other tool variations can incorporate the number of people exposed and level of turning away risk. The general term of these tools is 'relative ranking', or 'rapid ranking'. Qualitative risk assessment approaches stratifying multidisciplinary risk levels (RLs) must emphasize practicality for OSHH professional acceptance. This simplified transparency was found within publications behind the creation of the Control of Substances Hazardous to Health (COSHH) Essentials CB toolkit. Here, Brooke outlined three criteria for the toxicological basis of this approach: (1) simple and transparent, (2) make best use of available hazard information, and (3) recommend control strategies that vary according to degree of health hazard ${ }^{20)}$. In writing about the development of the COSHH Essentials model, Maidment stressed the importance of limiting the number of factors in the model to control its complexity and applicability ${ }^{21)}$. These simplified bands of risk, or RLs, link it with a commensurate control system and risk matrix harkening back to its safety origins. The RL approach at LLNL bands risk across four levels to obtain simplicity (Fig. 1). This RL matrix approach has successfully been put into practice at LLNL in a qualitative risk assessment program to prevent nanoparticulate exposure ${ }^{22)}$. Reaching across the

\begin{tabular}{c|c|c|c|c|c|}
\multicolumn{1}{c|}{ Probability } \\
\cline { 2 - 6 } & $\begin{array}{c}\text { Extremely } \\
\text { Unlikely }\end{array}$ & Less Likely & Likely & Probable \\
\hline $\begin{array}{c}\text { Very High } \\
\text { (serious injury } \\
\text { or illness) }\end{array}$ & RL 3 & RL 3 & RL 4 & RL 4 \\
\cline { 2 - 6 } $\begin{array}{c}\text { High } \\
\text { (lost work } \\
\text { time) }\end{array}$ & RL 2 & RL 2 & RL 3 & RL 4 \\
\hline $\begin{array}{c}\text { Medium } \\
\text { (recordable) }\end{array}$ & RL 1 & RL 1 & RL 2 & RL 3 \\
\hline $\begin{array}{c}\text { Low } \\
\text { (up to first } \\
\text { aid) }\end{array}$ & RL 1 & RL 1 & RL 1 & RL 2 \\
\hline
\end{tabular}

Fig. 1. Risk level (RL) matrix with Control Documentation as the Output.

RL 1: OK. Employees perform work under bi-annual application or approval. No oversight by OSHH disciplines necessary.

RL 2: Log. Established tasks with approved controls, recorded by supervisor. Periodic review of the tasks, procedures, and controls by OSHH disciplines is necessary.

RL 3: Permit. ES\&H Team and supervisor review of the hazards and controls (1 page). Supervisor and cognizant OSHH disciplines need to formally concur.

RL 4: Controlling Document. A thorough review of hazards and controls with the ES\&H Team, workers, and supervisors is performed and documented.
OSHH disciplines, this matrix is also the basis for barrier banding ${ }^{23)}$ and a burgeoning multidisciplinary approach for an ORM construction toolbox ${ }^{10,24)}$. This RL matrix has also been determined to be best suited for the unique needs of LLNL's workforce. It provides versatility in addressing both complex issues like nanomaterials and multidisciplinary approaches like with construction. The RL matrix also calibrates LLNL ES\&H Team risk perceptions, reducing intra-discipline variability or, statistically put, Type II error, when the assumption is that disciplines will respond the same, but in reality do not.

\section{Regulatory compliance}

Some aspects of risk assessment, ORM, and regulatory compliance have been around for a long time, but not necessarily as an accepted practice. The US White House Office of Management and Budget recently released risk assessment guidelines in 2006, describing them as "clear, minimum standards for the scientific quality of federal agency risk assessments". When the National Research Council reviewed these guidelines, it concluded that they were "fundamentally flawed" from a scientific and technical viewpoint and recommended withdrawing them in favor of an approach drawing on existing risk assessment expertise already within federal organizations ${ }^{25}$. Another example of this at a government level is with the Precautionary Principle, which has become part of international law. This principle has become the basis for European environmental legislation; however, a high level of uncertainty exists and there is still a standard of proof needed before utilizing this principle ${ }^{26)}$. LLNL ES\&H Team disciplines have consistently developed successful expert systems to balance their workload. Recently, with increasing regulatory requirements, related paperwork, and pervasive deadlines, the OSHH disciplines have found limitations in maintaining a field presence. The RL matrix approach was initially developed to provide a consistent method for documentation requirements. The RL control document process as seen in Fig. 1 provides a graded approach for ES\&H Team involvement based on the RL of tasks and procedures.

All involved parties incorporate the traditional hierarchy of controls in order to provide a consistent hazard elimination process to mitigate employee risk. Tasks with an RL1 designation are primarily work performed by the general public and a common sense procedure approach is presumed. Tasks with an RL2 designation are commonly performed by industry; however, they may require certain standardized controls to ensure regulatory compliance. RL2 tasks do require some level of assurance that these controls are consistently in place. Having a supervisor's record of these tasks in a designated logbook works well. ES\&H Team technicians and disciplines can 
audit these activities with the supervisor during workplace visits, ensuring work performed is within scope and established controls are in place. As RL1 and RL2 activities comprise a majority of standardized tasks at LLNL, this cost-effective method ensures health and safety regulatory compliance by focusing on risk ${ }^{24}$.

RL1 and RL2 activities also afford workers an opportunity to take credit for their training and job-specific expertise while minimizing ES\&H Team involvement. The RL3 designation is for work relating to either a higher level of potential risk, including regulatory non-compliance, or inappropriately characterized exposure potential. RL3 tasks require a standardized one-page permit as a higher level of control documentation in justifying the implemented controls will reduce risks relative to operative OELs. For primarily safety-related risks, such as roof work, confined space entry, welding, or other hot work activities, the permit ensures that potential risks are addressed, controls are in place, and the worker's training is commensurate to the task. For health-related risks, such as potential chemical exposure requiring respirators in addition to other standardized personal protection equipment (or PPE, such as glove selection, clothing, hearing protection, etc.), the permit is also a regulatory compliance document. Health-related permits include tasks with potential exposures to asbestos, lead, silica dust, carcinogens, and other common maintenance and support activities. Once procedures, or combined tasks, are deemed to have an RL4 designation, the controlling documents that are required by LLNL policy are required. RL4 work relates to the highest level of potential health and safety risk where the application of the traditional hierarchy of controls, in isolation, could remain ineffective at reducing or eliminating the multiple risks presented. As these RL4 designations are typically multidisciplinary OSHH activities involving complex work, a number of controlling documents can be utilized, including an Integration Work Sheet (IWS), a Hazard Assessment and Control (HAC) document, or a combination of the two. An IWS is a more thorough documenting process then a
HAC as a review and concurrence by responsible parties and authorization for potentially hazardous work is electronically tracked. IWS structure includes a multidisciplinary review of the broader hazards and controls relating to the established scope of work, with the chain of command concurring on this broad scope of work, whereas a HAC may record similar hazards and controls, but is narrower in scope and contains more detail.

This RL process finds its elegance in standardization of the most commonly performed tasks. This in turn standardizes risk, document generation, and approaches beneficial in addressing regulatory compliance. RLBMS processes maximize resources and achieve risk calibration and consistency of controls across OSHH disciplines. This assists planning and initiation of complicated LLNL $R \& D$ projects for the clients of ES\&H Teams. Historically, ES\&H Teams have been coerced by tradition or policy-generated workloads to treat all RLs with the same level of priority. As regulatory compliance issues are consistent and pervasive for ES\&H Teams, workload prioritization remained difficult. As a result, the highest priority is either the closest deadline or the loudest client. Prioritizing ES\&H Team involvement with work activities by RL and standardized tasks has offered an opportunity to change this dynamic. By involving ES\&H Teams in a graded approach as determined by risk of a given activity, the ES\&H Team disciplines and technicians can focus their time, expertise, and resources where most needed - the activities that have the highest potential for an adverse health and safety outcome (Fig. 2).

This RLBMS approach, in theory, has multiple outcomes that support all aspects of a traditional OHSMS with the added benefit of coordinating an approach supporting OSHH disciplines' field time, maximizing available resources, and minimizing $\mathrm{R} \& \mathrm{D}$ costs on a consistent basis. Establishing appropriate RLs for their related tasks and ensuring hazards and controls are consistently implemented are now prioritized. To assist this intensive process, we begin by maximizing the input and involvement of the resource most often overlooked in the devel-

\section{Risk Level breakdown Typical ES\&H oversight Ideal ES\&H oversight model}

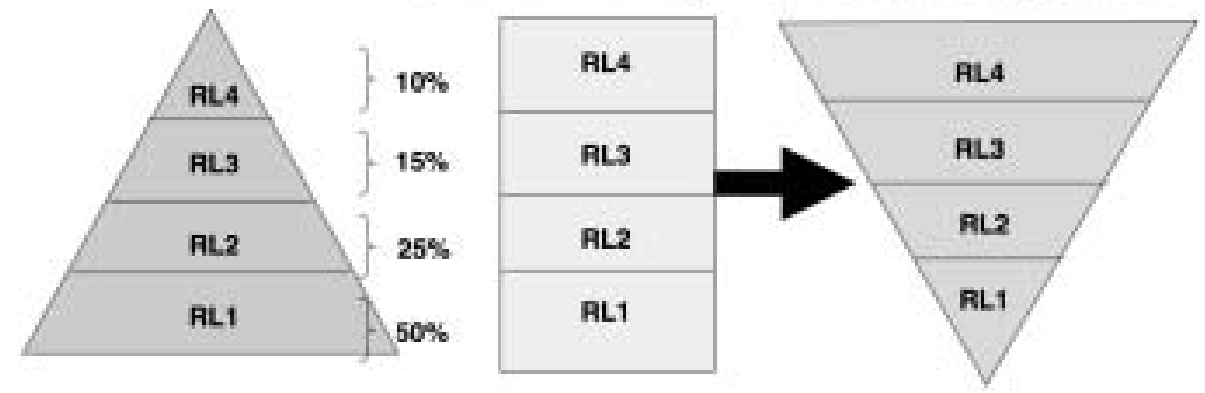

Fig. 2. Risk level approach to optimizing ES\&H Team capabilities. 
opment of OHSMSs — the worker.

\section{Participatory approach}

Successful OHSMS performance is often based on lagging indicators like frequency rates and lost time workrelated injury and illness. Often ignored are the attitudes and perceptions of workers in this process, an essential component of a healthy and safe work climate. Harnessing workers' input and involvement in OHSMS development can be a powerful management tool ${ }^{27)}$. Worker attitudes toward accident prevention in relation to management commitment and level of involvement are important for promoting safe workplaces. Appropriate risk perception was found to be significantly correlated to risk behavior and is related to the occurrence of accidents and near misses ${ }^{28)}$. Therefore, an employee's safe work attitude can be positively influenced when they consider themselves an integral part of a safety culture approach. This attitude as enhanced with a participatory OHSMS program, can itself be a measurable performance indicator of a successful safe and healthy workplace ${ }^{29)}$.

Though worker participation in reducing workplace hazards is often called for in research, underlying ideologies of management control and worker empowerment need to be fully understood to ensure a long lasting participation in practice over time ${ }^{17,30)}$. Participatory approaches focusing on worker input to achieve good practices and acceptable controls have an excellent track record of successful implementation over time and for establishing improvements in technical areas including materials handling, ergonomics, and comprehensive work $\operatorname{organization}^{31,32)}$. Once participatory methods for developing risk assessments are in practice, ongoing facilitation with training tools, checklists, and group involvement assists in maintaining and evaluating these applications positively $^{32)}$.

The RLBMS is therefore the nexus of the participatory approach and an OHSMS, where OSHH discipline expertise and collective worker input meet. Building an effective corporation requires this comprehensive feedback approach as it tears down existing preconceptions, rules, and institutional customs in order to build a more effective and functional health and safety system ${ }^{34)}$. OSHH field practitioners have an understanding of the workforce that is necessary to identify existing practices and organizational structures to determine the correct organizational direction. OSHH practitioners are also in an appropriate position to promote a positive course for management to enhance their organization. Conversely, with a lack of productivity and profitability identified in an existing health and safety system, OSHH disciplines must also identify these weaknesses to ensure the negative organizational direction does not persist.
Participatory methods in the collective redefining and rebuilding of a health and safety organizational structure has been shown to achieve the buy-in of managers and workers alike as this approach assists in achieving a collective vision of the ideals, objectives, and goals of a successful, organizationally-specific, OHSMS.

The roles of workers and expertise of OSHH field practitioners have assisted in the creation of the RLBMS and its bottom-up approach. At LLNL, the ES\&H Teams were an essential part in not just raising the consistent issues facing them over the years, but also in their persistence in developing solutions that are positive for everyone involved. The RLBMS is an integration of multiple solutions to regulatory compliance and policy issues that had worked themselves into the crevices of all aspects of R\&D operations. Through this, the RLBMS was compiled and sold to upper management as a benefit to operations and a cost-effective approach for highly stressed and shrinking ES\&H Teams. With over two thousand IWSs and similar controlling documents in place, unraveling this web of procedures, hazards, and controls appeared insurmountable. At this point, the role of the workers and the development of a teamwork approach to address this project were formulated.

\section{Results}

In implementing the participatory approach, ES\&H Teams met with their clients and began focusing on the most commonly performed tasks. Teams of affected workers, supporting ES\&H Team staff, and management representatives sat down at meetings designed to develop this approach. With procedures identified and tasks isolated, the workers described how these tasks should be performed safely. Delineated during this process were R\&D related activities that could not be standardized and required more time and energy in the development of a system to control these hazards. For the more commonly performed activities, ES\&H Team staff assisted in aligning hazard-to-control designations for tasks and assigned RLs based on the depth and integrity of supporting data. Management involvement in this process was limited to assuring final product quality and understanding needs and expectations of their workers on a first hand basis. Together, once agreements were reached, next steps were in documenting the approach, training, and procedural requirements to maintain this system over time. This process became invaluable for receiving worker buy-in and implementation.

As might be expected, not all team conclusions were in agreement. Workers would at times prefer less PPE, especially respiratory protection, but ES\&H Team regulatory-related data could not support a lower RL without 
Table 1. Negative Exposure Assessments for common activities in wallboard with asbestos containing building material (ACBM). Regulatory requirements will not permit an RL1

\begin{tabular}{|c|c|c|c|c|c|}
\hline Task & $\begin{array}{l}\text { Task Description and Limitations } \\
\text { (within } 30 \mathrm{~min} \text { ) }\end{array}$ & $\begin{array}{l}\text { Wallboard } \\
\text { Profile }\end{array}$ & Controls & Data Obtained & $\begin{array}{l}\text { Risk } \\
\text { Level }\end{array}$ \\
\hline 1 & Hammering up to 12,2 inch nails & $\begin{array}{l}\text { ACBM in } \\
\text { Joint Mud }\end{array}$ & $\begin{array}{l}\text { Shaving Gel over penetration, } \\
\text { wet rag to wipe up area }\end{array}$ & $\begin{array}{c}\mathrm{N}=14 \\
\text { 95th } \mathrm{UCL}=0.028 \text { fibers/cc }\end{array}$ & RL2 \\
\hline 2 & Installation of up to 8 lag bolts in wallboard & $\begin{array}{l}\text { ACBM in } \\
\text { Joint Mud }\end{array}$ & $\begin{array}{l}\text { Shaving Gel over penetration, } \\
\text { wet rag to wipe up area }\end{array}$ & $\begin{array}{c}\mathrm{N}=11 \\
\text { 95th } \mathrm{UCL}=0.041 \text { fibers } / \mathrm{cc}\end{array}$ & RL2 \\
\hline 3 & Up to 12,1 inch hole saw penetrations & $\begin{array}{l}\text { ACBM in } \\
\text { Joint Mud }\end{array}$ & $\begin{array}{l}\text { Shaving Gel over penetration, } \\
\text { wet rag to wipe up area }\end{array}$ & $\begin{array}{c}\mathrm{N}=12 \\
\text { 95th } \mathrm{UCL}=0.027 \text { fibers/cc }\end{array}$ & RL2 \\
\hline 4 & Twist drilling 11 ( $3 / 8$ inch) molly bolts & $\begin{array}{l}\text { ACBM in } \\
\text { Joint Mud }\end{array}$ & $\begin{array}{l}\text { Shaving Gel over penetration, } \\
\text { wet rag to wipe up area }\end{array}$ & $\begin{array}{c}\mathrm{N}=7 \\
\text { 95th } \mathrm{UCL}=0.026 \text { fibers/cc }\end{array}$ & RL2 \\
\hline 5 & $\begin{array}{c}\text { Installation of up to } 8 \text { lag bolts through } \\
\text { frames }\end{array}$ & $\begin{array}{l}\text { ACBM in } \\
\text { Joint Mud }\end{array}$ & $\begin{array}{l}\text { Shaving Gel over penetration, } \\
\text { wet rag to wipe up area }\end{array}$ & $\begin{array}{c}\mathrm{N}=8 \\
\text { 95th } \mathrm{UCL}=0.025 \text { fibers } / \mathrm{cc}\end{array}$ & RL2 \\
\hline 6 & $\begin{array}{l}\text { Twist drilling and installation of } 11 \text { molly } \\
\text { bolts }\end{array}$ & $\begin{array}{l}\text { ACBM in } \\
\text { Joint Mud }\end{array}$ & $\begin{array}{l}\text { Shaving Gel over penetration, } \\
\text { wet rag to wipe up area }\end{array}$ & $\begin{array}{c}\mathrm{N}=7 \\
\text { 95th } \mathrm{UCL}=0.026 \text { fibers } / \mathrm{cc}\end{array}$ & RL2 \\
\hline 7 & Patching holes to be exposed in work area & $\begin{array}{l}\text { ACBM in } \\
\text { Joint Mud }\end{array}$ & $\begin{array}{l}\text { Shaving Gel over penetration, } \\
\text { wet rag to wipe up area }\end{array}$ & $\begin{array}{c}\mathrm{N}=9 \\
\text { 95th } \mathrm{UCL}=0.069 \text { fibers } / \mathrm{cc}\end{array}$ & RL2 \\
\hline 8 & $\begin{array}{c}\text { Removing of frames allowing } 15 \text { holes to be } \\
\text { exposed in work area }\end{array}$ & $\begin{array}{l}\text { ACBM in } \\
\text { Joint Mud }\end{array}$ & $\begin{array}{l}\text { Shaving Gel over penetration, } \\
\text { HEPA vacuum behind frame }\end{array}$ & $\begin{array}{c}\mathrm{N}=7 \\
\text { 95th } \mathrm{UCL}=0.026 \text { fibers/cc }\end{array}$ & RL2 \\
\hline
\end{tabular}

quantified personal monitoring results. In these cases, assigning a higher RL was temporarily necessary. The protocol necessary to make quantitative and statisticallybased decisions on requirements to reduce RLs was established when practicable. At times different RLs were derived by ES\&H Team disciplines for similar, common tasks. These issues were raised by the cognizant OSHH disciplines in previously established weekly meetings as a topic for discussion and agreement. This process was successful on many levels, but especially in calibrating risk perception within and between the ES\&H Teams and their disciplines.

\section{RLBMS in practice}

The following topics, with the exception of 'Safety', provide concise, practical examples of our existing excel spreadsheet 'database' of tasks, controls, monitoring, statistically-based results, and our process for assigning RL2s (e.g. taking off the respirators) for various tasks. OSHH field disciplines respond consistently to hazardous tasks by implementing the hierarchy of controls: elimination, substitution, engineering, administrative and lastly, PPE. This process has been applied to each task example given in the topics presented below.

\section{Asbestos}

Tasks that were most commonly performed were targeted operations for monitoring and development of controls. Workers identified the activities most performed and assisted in standardizing simplified controls in a participatory process including IHs and managers. IH professionals then designed sampling protocol that worked best with the asbestos OEL, fitting the amount of work to be done within a 30-min period as the Excursion Limit of 1.0 fibers per cubic centimeter $(\mathrm{f} / \mathrm{cc})$ is an order of magnitude higher then the 8-h TWA (8-h Time Weighted Average) of $0.1 \mathrm{f} / \mathrm{cc}$. Therefore, as seen in Table 1, the RL2 designation was given to tasks that were $30 \mathrm{~min}$ or less with cumulative results below $0.1 \mathrm{f} / \mathrm{cc}$ (an order of magnitude below, or $10 \%$ of, the effective OEL) as an in-house standard ${ }^{35}$.

It has been determined where the employer has monitored each asbestos job and how data during work tasks, and under workplace conditions closely resembling the processes, was obtained for compliance purposes. Conditions for workplace conditions include the type of material, control methods, work practices, environmental conditions, and prevailing environmental conditions in the employer's current operations. With this information the employer may rely on such monitoring results to satisfy FedOSHA regulations ${ }^{36)}$.

\section{Beryllium}

Work with beryllium poses an interesting dilemma at DOE with its unique regulatory criteria, but even more so at LLNL where surface levels of beryllium delineate beryllium work, reflecting potential dermal exposure, not airborne levels which are more typically OEL-based criteria. Therefore, the RLBMS for beryllium requires delineating ES\&H Team involvement at RL1, rather than at the customary RL2. This conservative approach reflects the potential of beryllium surface levels above the release criteria of 0.2 micrograms per 100 square centimeters $\left(\mu \mathrm{g} / 100 \mathrm{~cm}^{2}\right)$ as is seen in Table 2; therefore RL1 is the 
Table 2. Beryllium (Be) work Risk Level (RL) approach

\begin{tabular}{|c|c|c|c|c|c|}
\hline Risk Level & Potential Exposure & Controls Required & Documentation & Required Sampling & Training \\
\hline RL1 & No dermal and no inhalation & None & $\begin{array}{l}\text { Designated CL1 } \\
\text { task }\end{array}$ & $\begin{array}{l}\text { Baseline obtained to } \\
\text { confirm designation }\end{array}$ & Be Awareness \\
\hline RL2 & Dermal potential, no inhalation & $\begin{array}{l}\text { Be Work Area (BWA): } \\
\text { Gloves (Long Sleeves, } \\
\text { Booties possible) }\end{array}$ & $\begin{array}{l}\text { IH report \& surface } \\
\text { sampling }\end{array}$ & $\begin{array}{c}\text { Air \& surface; need } \\
\text { solid objective data } \\
\text { (SOD) to become CL1 }\end{array}$ & $\begin{array}{c}\text { Be Worker + } \\
\text { Medical } \\
\text { Surveillance }\end{array}$ \\
\hline RL3 & $\begin{array}{c}\text { Dermal }+ \text { inhalation, confi- } \\
\text { dence airborne is }<0.2 \mu \mathrm{g} / \mathrm{m}^{3} \\
\text { 8-h TWA }\end{array}$ & $\begin{array}{c}\text { BWA: Gloves (Tyvek \& } \\
\text { Booties necessary), Respirator } \\
\text { (1/2 mask) }\end{array}$ & $\begin{array}{l}\text { Be Permit, IH } \\
\text { report \& air, surface } \\
\text { sampling }\end{array}$ & $\begin{array}{l}\text { Air \& surface; need } \\
\text { SOD to become CL2 }\end{array}$ & $\begin{array}{c}\text { Be Worker + } \\
\text { Medical } \\
\text { Surveillance }\end{array}$ \\
\hline RL4 & $\begin{array}{c}\text { Dermal }+ \text { inhalation, no confi- } \\
\text { dence airborne is }<0.2 \mu \mathrm{g} / \mathrm{m}^{3} \\
\text { 8-h TWA }\end{array}$ & $\begin{array}{c}\text { Regulated BWA: Gloves } \\
\text { (Tyvek \& Booties necessary), } \\
\text { Respirator (Full face) }\end{array}$ & $\begin{array}{l}\text { HAC document. } \\
\text { IH report \& air, } \\
\text { surface sampling }\end{array}$ & $\begin{array}{l}\text { Air \& surface; need } \\
\text { SOD to become CL3 }\end{array}$ & $\begin{array}{l}\text { Be Worker + } \\
\text { Medical } \\
\text { Surveillance }\end{array}$ \\
\hline
\end{tabular}

Beryllium work is defined as the potential for airborne or dermal exposure above the release criteria for all workers.

category that workers seek to attain.

To achieve RL1, a determination is made that there no potential for dermal exposure; therefore, a quantification of surface measurements is necessary and achieved by collecting wet swipes in and around work areas. Achieving RL2 requires statistically ensuring there is no potential for airborne beryllium levels approaching the Action Level of 0.2 micrograms per cubic meter $\left(\mu \mathrm{g} / \mathrm{m}^{3}\right)$ as an 8-h TWA. If such data is not available, the resulting control designation is RL3, or RL4 if there is a potential to be in excess of the Action Level. These RL delineations reflect DOE regulatory criteria and provide a necessary consistency for IH decision-making. Beneficially, it also offers clarity for workers who may work in proximity to beryllium components or related contamination. Therefore, IHs who routinely quantify surface and personal exposures within established or potential Beryllium Work Areas (BWAs) are more likely to have established controls effectively lowering the RL more consistently. It is important to highlight regulatory oversight specific to beryllium as FedOSHA's Permissible Exposure Limit, currently at $2.0 \mu \mathrm{g} / \mathrm{m}^{3}$ as an 8-h TWA and identified within the DOE criteria, is an order of magnitude higher than the Action Level.

Lead

RLs were determined for four different types of activities involving potential exposure to lead and are shown in Table 3. The activities were defined as activity Similar Exposure Groups (SEGs). These activities were monitored to satisfy FedOSHA lead monitoring requirements, however the data also assigns appropriate RLBMS classifications. To illustrate this, only the most pertinent information is shown.

In Table 3, RLs were determined from personal exposure data from the four operations. Brick transport and dirt removal activities were initially characterized as RL 3 operations prior to obtaining exposure data; however, based on a minimum of six samples obtained for each activity and calculation of Land's "Exact" 95\% upper confidence level (UCL), the RL was downgraded to RL 2. Hence, these activities would no longer require respiratory protection or a lead work permit. For the paint removal activity, as only one data point was obtained, additional exposure data would be required before RL downgrading is possible.

\section{Silica}

RLs were determined for six different activities (including three pertaining to saw cutting, but on different materials or with different controls) involving potential exposure to respirable crystalline silica (silica) and are shown in Table 4.

For rotohammering, two different control options are available and both are determined as RL2, or no required respiratory protection. For two of the five activities, the OEL for silica was exceeded, even with engineering controls in place. These activities were therefore designated as RL 3 and require silica work permits and further IH monitoring, with an emphasis on upgrading the engineering controls to reduce exposures as practicable.

\section{Safety}

RLs for life-critical activities are initially determined as RL3. The proactive process begins by evaluating the activity's full scope and potential RL3 activities to be performed in line with the project as part of a pre-job briefing $^{24)}$. Controls commensurate to these RL3 items are identified in advance and a daily project walk-through with a checklist, as in Table 5, is performed. Since controls related to each item are previously identified as in place, they are considered RL2.

This checklist assessment approach not only identifies compliance and non-compliance with FedOSHA regulations, deficiencies that are rectified simply in the field can be recorded as a 'near-miss'. These checklists are also 
Table 3. Activity SEG descriptions and corresponding RL determinations for work involving potential exposure to airborne lead, these are examples of classification and not cumulative results

\begin{tabular}{|c|c|c|c|c|c|c|c|c|c|c|}
\hline Category & Description & $\begin{array}{l}\text { Sampling } \\
\text { duration (min) }\end{array}$ & $\begin{array}{l}\text { Results } \\
\left(\mu \mathrm{g} / \mathrm{m}^{3}\right)\end{array}$ & $\begin{array}{l}\text { 8-h TWA } \\
\left(\mu \mathrm{g} / \mathrm{m}^{3}\right)\end{array}$ & $\begin{array}{l}\text { Eng } \\
\text { Controls }\end{array}$ & Admin Controls & PPE & $\begin{array}{l}\text { OEL } \\
\left(\mu \mathrm{g} / \mathrm{m}^{3}\right)\end{array}$ & $>\mathrm{OEL}$ & $\begin{array}{l}\text { Risk Level } \\
\text { (RL) }\end{array}$ \\
\hline Soldering & $\begin{array}{l}\text { Electric soldering } \\
\text { using } \operatorname{Sn} 63(37 \% \\
\mathrm{Pb}) \text { solder }\end{array}$ & $\begin{array}{l}77,347,332, \\
207,235\end{array}$ & $\begin{array}{l}<1.5,<0.6, \\
<0.6,<1.0, \\
<0.8\end{array}$ & $\begin{array}{l}<0.24,<0.43, \\
<0.43,<0.72, \\
<0.58\end{array}$ & $\begin{array}{l}\text { General } \\
\text { ventilation }\end{array}$ & None & None & 50 & No & RL1 \\
\hline $\begin{array}{l}\text { Brick } \\
\text { transport }\end{array}$ & $\begin{array}{l}\text { Transport of } 480 \\
\text { bricks from old } \\
\text { pallets onto new } \\
\text { pallets }\end{array}$ & $\begin{array}{l}111,117,110, \\
96,103,101\end{array}$ & $\begin{array}{l}1.8,5,24 \\
5,6.4,6.7\end{array}$ & $\begin{array}{l}0.42,1.2,5.5, \\
1.0,1.4,1.4 \\
\text { (Land's "Exact" } \\
95 \% \text { UCL=7.0) }\end{array}$ & Outdoors & $\begin{array}{l}\text { Lead Work } \\
\text { Permit, Lead } \\
\text { Training, Water } \\
\text { spray and wet } \\
\text { wipe. prior to } \\
\text { transport }\end{array}$ & $\begin{array}{l}\text { C, LG \& NG, HF, } \\
\text { shoe covers, safe- } \\
\text { ty glasses, Hudson } \\
\text { sprayer }\end{array}$ & 50 & No & $\begin{array}{l}\text { RL2 } \\
\text { (Based on } \\
\text { results, HF or } \\
\text { lead work per- } \\
\text { mit not required } \\
\text { with controls) }\end{array}$ \\
\hline $\begin{array}{l}\text { Paint } \\
\text { removal }\end{array}$ & $\begin{array}{l}\text { Wet-scrape paint } \\
\text { using HEPA vac- } \\
\text { uum }\end{array}$ & 94 & $<2.1$ & $<0.41$ & $\begin{array}{l}\text { HEPA } \\
\text { vacuum }\end{array}$ & $\begin{array}{l}\text { Lead Work } \\
\text { Permit, Lead } \\
\text { Training }\end{array}$ & $\begin{array}{l}\mathrm{C}, \mathrm{NG}, \mathrm{HF} \text {, safety } \\
\text { glasses }\end{array}$ & 50 & No & $\begin{array}{l}\text { RL3 } \\
\text { (More data } \\
\text { required to } \\
\text { reduce RL) }\end{array}$ \\
\hline Dirt removal & $\begin{array}{l}\text { Removal of lead- } \\
\text { contaminated dirt } \\
\text { at pistol range }\end{array}$ & $\begin{array}{l}278,277,51 \\
54,172,170\end{array}$ & $\begin{array}{l}0.57,1.5 \\
<3.0,<2.9 \\
1.0,<0.92\end{array}$ & $\begin{array}{l}0.30,0.87, \\
<0.32,<0.33, \\
0.36,<0.33 \\
\text { (Land's "Exact" } \\
95 \% \text { UCL=0.64) }\end{array}$ & $\begin{array}{l}\text { Water } \\
\text { spray }\end{array}$ & $\begin{array}{l}\text { Lead Work } \\
\text { Permit, did not } \\
\text { overfill bucket } \\
\text { used for dirt } \\
\text { transport }\end{array}$ & $\begin{array}{l}\text { C, NG, HF, safety } \\
\text { glasses }\end{array}$ & 50 & No & $\begin{array}{l}\text { RL2 } \\
\text { (Based on } \\
\text { results, HF or } \\
\text { permit not } \\
\text { required with } \\
\text { controls) }\end{array}$ \\
\hline
\end{tabular}

C=Tyvek coveralls, LG=Leather Gloves, NG=Nitrile Gloves, $\mathrm{HF}=$ Half-face air purifying respirator.

Table 4. Activity SEG descriptions and corresponding RL determinations for work involving potential exposure to silica dust. These are examples of classification and not cumulative results

\begin{tabular}{|c|c|c|c|c|c|c|c|c|c|c|}
\hline Category & Description & $\begin{array}{l}\text { Sampling } \\
\text { duration (min) }\end{array}$ & $\begin{array}{l}\text { Results } \\
\left(\mu \mathrm{g} / \mathrm{m}^{3}\right)\end{array}$ & $\begin{array}{l}\text { 8-h TWA } \\
\left(\mu \mathrm{g} / \mathrm{m}^{3}\right)\end{array}$ & Eng Controls & $\begin{array}{l}\text { Admin } \\
\text { Controls }\end{array}$ & PPE & $\begin{array}{l}\text { OEL } \\
\left(\mu \mathrm{g} / \mathrm{m}^{3}\right)\end{array}$ & $>\mathrm{OEL}$ & $\begin{array}{l}\text { Risk Level } \\
\text { (RL) }\end{array}$ \\
\hline $\begin{array}{l}\text { Rotoham- } \\
\text { mering }\end{array}$ & $\begin{array}{l}\text { Drilling holes up to } \\
20 \text { holes, up to } 4 \\
\text { inches deep, into a } \\
\text { concrete slab or floor } \\
\text { using a rotohammer. }\end{array}$ & $\begin{array}{l}\text { Over } 20 \text { sam- } \\
\text { ples. } \\
\text { Various times } \\
\text { from } 30-180 \\
\text { min }\end{array}$ & $\begin{array}{l}<\text { Limit of } \\
\text { Detection }\end{array}$ & $\begin{array}{l}\text { Not } \\
\text { Applicable }\end{array}$ & $\begin{array}{l}2 \text { methods: } \\
\text { 1) HEPA vacuum } \\
\text { at drill site; or } \\
\text { 2) wet cloth } \\
\text { around hole }\end{array}$ & $\begin{array}{l}\text { Silica safety } \\
\text { training }\end{array}$ & C, LG, HP, no R & 25 & No & RL 2 \\
\hline $\begin{array}{l}\text { Jack ham- } \\
\text { mering }\end{array}$ & $\begin{array}{l}\text { Breaking up a con- } \\
\text { crete floor using a } \\
\text { jackhammer }\end{array}$ & 205 & 180 & 77 & $\begin{array}{l}\text { Ventilated enclo- } \\
\text { sure, wet method, } \\
\text { local exhaust }\end{array}$ & $\begin{array}{l}\text { Silica safety } \\
\text { training }\end{array}$ & C, LG, HP, FF-R & 25 & Yes & RL 3 \\
\hline Saw cutting & $\begin{array}{l}\text { Cutting concrete floor } \\
\text { using concrete saw }\end{array}$ & 70 & 60 & 8 & $\begin{array}{l}\text { Ventilated enclo- } \\
\text { sure, wet method, } \\
\text { local exhaust }\end{array}$ & $\begin{array}{l}\text { Silica safety } \\
\text { training }\end{array}$ & $\mathrm{C}, \mathrm{LG}, \mathrm{HP}, \mathrm{FF}-\mathrm{R}$ & 25 & No & $\begin{array}{l}\text { RL } 3 \\
\text { (More data } \\
\text { required to } \\
\text { reduce RL) }\end{array}$ \\
\hline Saw cutting & $\begin{array}{l}\text { Cutting asphalt side- } \\
\text { walk }\end{array}$ & 68 & 90 & 13 & None & $\begin{array}{l}\text { Silica safety } \\
\text { training }\end{array}$ & HF-R & 25 & No & $\begin{array}{l}\text { RL } 3 \\
\text { (More data } \\
\text { required to } \\
\text { reduce RL) }\end{array}$ \\
\hline Saw cutting & Cutting asphalt floor & 85 & $<47$ & $<8$ & $\begin{array}{l}\text { Wet methods } \\
\text { (hoseline sprayer) }\end{array}$ & $\begin{array}{l}\text { Silica safety } \\
\text { training }\end{array}$ & $\begin{array}{l}\text { Double HP, hard } \\
\text { hat, PA-R. anti- } \\
\text { vibration boots } \\
\text { and gloves, }\end{array}$ & 25 & No & $\begin{array}{l}\mathrm{RL} 3 \\
\text { (More data } \\
\text { required to } \\
\text { reduce } \mathrm{RL} \text { ) }\end{array}$ \\
\hline Chipping & $\begin{array}{l}\text { Chipping concrete } \\
\text { using chipping gun }\end{array}$ & 201,305 & 120,50 & 68,31 & $\begin{array}{l}\text { Ventilated enclo- } \\
\text { sure, wet method, } \\
\text { local exhaust }\end{array}$ & $\begin{array}{l}\text { Silica safety } \\
\text { training }\end{array}$ & C, HP, LG, FF-R & 25 & Yes & RL 3 \\
\hline
\end{tabular}

$\mathrm{C}=$ Coveralls, $\mathrm{LG}=$ Leather Gloves, HP=Hearing Protection, $\mathrm{HF}=$ Half-face, $\mathrm{FF}=$ Full-face, $\mathrm{PA}=$ Powered air, R=Respirator.

to be available in an electronic format compatible with field inspections. Therefore, these inspections will also serve as a positive reinforcement mechanism trending percentages of field compliance, rather than non-compliance, as a leading indicator. This also serves as a quantified trending of areas requiring improvement (e.g., controls not in place), feeding into a quarterly tailgate training that focuses resources and attention where most warranted. This is intended to replace the more prominent lagging indicator of workplace accidents and injuries, which then 
Table 5. Example of an occupational safety assessment checklist

\begin{tabular}{|c|c|c|c|c|c|c|c|c|c|}
\hline & YES & NO & N/A & Items Assessed & & YES & No & N/A & Items Assessed \\
\hline & & & & Fall Prevention and Protection & & & & & Excavation and Trenching \\
\hline 1 & & & & $\begin{array}{l}\text { Employees are utilizing 100\% fall protection at/above } 6 \\
\text { feet }(2 \mathrm{~m}) \text {. }\end{array}$ & 22 & & & & Before digging, "utility locates" have been performed \\
\hline 2 & & & & $\begin{array}{l}100 \% \text { tie-off maintained at/above } 6 \text { feet }(2 \mathrm{~m}) \text { or when } \\
\text { exposed to a fall hazard. }\end{array}$ & 23 & & & & $\begin{array}{l}\text { Occupied excavations are adequately protected against } \\
\text { cave-in }\end{array}$ \\
\hline 3 & & & & Fall protection in use is in satisfactory condition & 24 & & & & $\begin{array}{l}\text { "Competent Person" daily inspections are completed prior } \\
\text { to excavation entry }\end{array}$ \\
\hline 4 & & & & $\begin{array}{l}\text { Employees will not contact a lower level obstruction } \\
\text { during an arrest }\end{array}$ & 25 & & & & $\begin{array}{l}\text { Adjacent equipment (stationary/mobile) is controlled to } \\
\text { prevent imminent danger to occupants }\end{array}$ \\
\hline \multirow[t]{2}{*}{5} & & & & $\begin{array}{l}\text { Floor/Wall openings are covered, protected and labeled } \\
\text { (i.e., load rating) }\end{array}$ & 26 & & & & $\begin{array}{l}\text { Employees are hand digging with non-conductive tools } \\
\text { while locating underground utilities }\end{array}$ \\
\hline & & & & $\begin{array}{l}\text { Electrical Safety and } \\
\text { Lockout/Tagout (LOTO) }\end{array}$ & & & & & Scaffolds \\
\hline 6 & & & & $\begin{array}{l}\text { A GFCI/CB/Assured Grounding/Earthing program is being } \\
\text { used where required }\end{array}$ & 27 & & & & $\begin{array}{l}\text { Scaffolds are installed, maintained and inspected per } \\
\text { requirements and possess scaffold tag }\end{array}$ \\
\hline 7 & & & & $\begin{array}{l}\text { All exposed conductors are covered by closed electrical } \\
\text { enclosures }\end{array}$ & 28 & & & & $\begin{array}{l}\text { Modification, erection and dismantling are performed only } \\
\text { by competent scaffold erectors }\end{array}$ \\
\hline 8 & & & & $\begin{array}{l}\text { Temporary wiring terminations are protected both } \\
\text { dielectrically and mechanically }\end{array}$ & 29 & & & & $\begin{array}{l}\text { Scaffolds are grounded where exposed to } \\
\text { induction/electrical conductors }\end{array}$ \\
\hline 9 & & & & $\begin{array}{l}\text { Ground prongs are present on extension cords and power } \\
\text { tools as required }\end{array}$ & & & & & Ladders \\
\hline 10 & & & & $\begin{array}{l}\text { Proper PPE is being used when working on energized } \\
\text { circuits }\end{array}$ & 30 & & & & $\begin{array}{l}\text { Metal ladders and multi purpose ladders are not being } \\
\text { used }\end{array}$ \\
\hline 11 & & & & $\begin{array}{l}\text { All applicable hazardous energies are isolated with an } \\
\text { attached LOTO device and tag and all residual/stored } \\
\text { energy relieved }\end{array}$ & 31 & & & & $\begin{array}{l}\text { Straight/Extension ladders are secured against } \\
\text { displacement }\end{array}$ \\
\hline 12 & & & & $\begin{array}{l}\text { Zero energy checks are being performed with a volt ohm } \\
\text { meter }\end{array}$ & 32 & & & & $\begin{array}{l}\text { Ladder positioning is adequate to perform work safely } \\
\text { (proper ladder angle) }\end{array}$ \\
\hline 13 & & & & $\begin{array}{l}\text { Each exposed individual has control over the lockout } \\
\text { device }\end{array}$ & 33 & & & & $\begin{array}{l}\text { Ladder is suitable for the task (e.g., extension vs. A- } \\
\text { frame) }\end{array}$ \\
\hline 14 & & & & $\begin{array}{l}\text { LOTO device emergency/absent removal protocols are } \\
\text { being followed }\end{array}$ & 34 & & & & $\begin{array}{l}\text { Employees are not standing on the top two rungs of } \\
\text { ladders }\end{array}$ \\
\hline 15 & & & & Proper insulated tools are being used for electrical work & 35 & & & & $\begin{array}{l}\text { Employees are maintaining 3-point contact while climbing } \\
\text { ladders }\end{array}$ \\
\hline \multirow[t]{2}{*}{16} & & & & Is the proper signage in place & & & & & Lifting/Rigging Operations \\
\hline & & & & Confined Space & 36 & & & & $\begin{array}{l}\text { Only qualified operators are operating hoists (stationary } \\
\text { and mobile) }\end{array}$ \\
\hline 17 & & & & $\begin{array}{l}\text { A full time attendant is present during confined space } \\
\text { entry }\end{array}$ & 37 & & & & Rigging operations are performed only by qualified riggers \\
\hline 18 & & & & $\begin{array}{l}\text { Confined space is being monitored for potential chemical } \\
\text { and atmospheric hazards }\end{array}$ & 38 & & & & $\begin{array}{l}\text { In-service rigging equipment is in satisfactory condition } \\
\text { (load limit tags, inspected, defect free, hoists) }\end{array}$ \\
\hline 19 & & & & Adequate rescue equipment is readily available & 39 & & & & All load hooks are equipped with safety latches \\
\hline 20 & & & & $\begin{array}{l}\text { The entry permit addresses all imminent dangers for } \\
\text { permit required confined spaces }\end{array}$ & 40 & & & & $\begin{array}{l}\text { Swing radius has been identified/barricaded with danger } \\
\text { tape or barricaded if needed }\end{array}$ \\
\hline 21 & & & & Is the proper signage in place & 41 & & & & $\begin{array}{l}\text { High voltage lines are shielded when hoisting and rigging } \\
\text { operations are within } 10 \text { feet }\end{array}$ \\
\hline
\end{tabular}

Potential RL3 items are RL2 when proactively identified, controls determined, and jobsite assessed to ensure compliance.

can be graded as a percentage of incidents over compliance rather than incidents in isolation.

\section{Discussion}

The RLBMS risk-based ORM model has begun to successfully focus dwindling OSHH expertise and resources at LLNL onto the highest risk procedures as originally intended. Utilizing the $\mathrm{CB}$ strategies in this unique approach has taken a large variety of commonly performed maintenance and support activities and integrated the RL approaches to maximize R\&D output. Another additional benefit for $R \& D$ activities is the tracking of R\&D tasks so, when placed within SEGs, they can be fur- ther standardized. Additionally, expanding the RLBMS SEG approach to include co-located workers will establish a quantified exposure connection within and between working environments to bolster medical surveillance selectivity. The majority of RLBMS tasks are routine and well defined within production-oriented companies and can therefore be shared. This is also true for R\&D environments with many support and maintenance tasks, but not with programmatic work. Where support and maintenance tasks may differ is in the work location itself, as workers may be exposed to co-located and unique facility hazards. Auditable tracking of these activities through the RL approach has also been successful in standardizing regulatory compliance and is proving to be useful for 
all levels of management.

Hand-in-hand with the maximization of OSHH prioritization of activities is a more confident workforce. Workers can now focus more on the quality of their product, rather than compliance, as emphasized in their role in developing their task-based controls. As presented, the regulatory documentation of hazard assessments and implemented controls offers a validation of the RLBMS. Consolidation of the measurement and evaluation of exposure control effectiveness for auditing purposes adds to the growing research emphasizing the utility of qualitative risk assessment approaches within a traditional framework ${ }^{39)}$. The RLBMS's participatory approach can be seen building effectiveness from the bottom up, teaming workers with OSHH staff in a collaborative manner that develops partnerships at an accelerated pace. The eventual linking of the RLBMS model into a comprehensive OSHH database, currently delayed due to budgetary constraints and now manually introduced into electronic spreadsheets, will eventually strengthen the calibration of risk-based decisions across OSHH disciplines. Currently, an auditable trail is demonstrating the benefits of the consistency inherent in the RLBMS approach. This consistency is an essential component of ensuring a healthy and safe working environment within a complicated regulatory framework.

\section{Conclusion}

RLBMS's simplicity belies the complexity of ensuring a consistent implementation strategy while adjusting OSHH resources to regulatory changes. RLBMS's auditable tracking of activities, maximization of OSHH professional field time, and standardization of control documentation is proving invaluable. Validation of RLs and evaluation of task-to-control effectiveness continues within a quantitative regime for regulatory auditing to ensure the appropriateness of qualitative risk assessment methods. The creation of an OHSMS protocol that integrates participatory approaches so intrinsically has also created a simplified and consistent risk communication that underscores the overall value of the RLBMS. It must also be made clear that the RLBMS should not be implemented in many organizations prima facie as there are varying levels of confidence in working with qualitative risk assessment techniques in any working environment. Therefore, a thorough review of the RLBMS and its components is highly recommended. National regulatory requirements, enforcement, and cultural acceptance of exposure assessment protocol can vary greatly. Organizations worldwide may find acceptable quantitative risk assessment protocol at $10 \%, 50 \%$, or $95 \%$ of established OELs, and at varying statistical confidence levels as well. Other organizations may feel it appropriate to operate above an OEL with respiratory protection and PPE in use. The RLBMS can be adapted to any of these regimes, however validation and evaluation will always be necessary to ensure worker health and safety remain paramount. Should others see RLBMS's utility, validated task-based controls can be captured in international databases and national programs, incorporating them into trade-based ORM toolboxes and further integrating OSHH professions to assist in a multidisciplinary reduction of work-related injury and illness worldwide.

\section{Acknowledgements}

This work performed, in part, under the auspices of the US Department of Energy by Lawrence Livermore National Laboratory under Contract DE-AC5207NA27344. LLNL-JRNL-413441.

\section{References}

1) Swuste P (2008) 'You will only see it, if you understand it', or occupational risk prevention from a management perspective. Hum Fact and Ergon in Manuf 18, 438-53.

2) Redinger $\mathrm{CF}$, Levine SP, Blotzer MJ, Majewski MP (2002) Evaluation of an Occupational Health and Safety Management System performance measurement toolII: scoring methods and field study sites. Am Ind Hyg Assoc J 63, 34-40.

3) Levine SP, Dyjacka DT (1997) Critical features of an auditable management system for an ISO 9000-compatible occupational health and safety standard. Am Ind Hyg Assoc J 58, 291-8.

4) Redinger CF, Levine SP (1998) Development and evaluation of the Michigan Occupational Health and Safety Management System assessment instrument: a universal OHSMS performance measurement tool. Am Ind Hyg Assoc J 59, 572-81.

5) Machida S (2001) Guidelines on occupational safety and health management systems (ILO/OSH 2001). AsianPacific Newslett Occup Health Safety 8, 72-3.

6) Kogi K (2002) Work Improvement and occupational safety and health management systems: common Features and research needs. Ind Health 40, 121-33.

7) Fingerhut $M$, Driscoll $T$, Imel Nelson $D$, ConchaBarrientos M, Punnett L, Pruss-Ustin A, Steenland K, Leigh J, Corvalan C (2005) Contribution of occupational risk factors to the global burden of disease - a summary of findings. Scand J Work Environ Health 1 (Suppl 1), 58-61.

8) Lingard H, Holmes N (2001) Understandings of occupational health and safety risk control in small business construction firms: barriers to implementing technological controls. Construc Manag \& Econ 19, 217-26.

9) Zalk DM, Nelson DI (2008) History and evolution of 
control banding: a review. J Occup Environ Hyg 5, $330-46$.

10) Fingerhut $M$ (2008) Global qualitative risk management (control banding) activities. Ind Health 46, 305-7.

11) Russel R, Maidment S, Brooke I, Topping M (1998) An introduction to a UK scheme to help small firms control health risks from chemicals. Ann Occup Hyg 45, $367-76$.

12) Naumann BD, Sargent EV, Starkman BS, Fraser WJ, Becker GT, Kirk GD (1996) Performance-based exposure control limits for pharmaceutical active ingredients. Am Ind Hyg Assoc J 57, 33-42.

13) Sargent E, Kirk G (1998) Establishing airborne exposure control limits in the pharmaceutical industry. Am Ind Hyg Assoc J 49, 309-13.

14) Swuste P (2004) Occupational hazards, risks, and solutions. Presentation at the 2nd International $\mathrm{CB}$ Workshop: Validation \& Effectiveness of Control Banding. March 1-2, Cincinnati.

15) Zalk DM (2006) Practical prevention in safety; from control banding to barrier banding. Proceedings 17(5), International Working on Safety Conference, 15 September 2006 Eemhof, The Netherlands.

16) Kogi K, Caple D (2008) Developing ergonomic checkpoints for facilitating practical improvement in smallscale workplaces. SY20-03, XVIII World Congress on Safety and Health at Work, Seoul.

17) Zalk DM (2001) Grassroots ergonomics: initiating an ergonomics program utilising participatory techniques. Ann Occup Hyg 45, 283-9.

18) Zwaard W, Passchier W (1995) Risicobepaling en risicobeheersing. Tijdschrift voor toegepaste Arbowetenschap 8, 8-12 (in Dutch).

19) Zwaard W, Goossens L (1997) Relatieve Ranking als hulpmiddel voor risico-evaluatie. Tijdschrift voor toegepaste Arbowetenschap 10, 10-5 (in Dutch).

20) Brooke IM (1998) A UK scheme to help small firms control health risks from chemicals: toxicological considerations. Ann Occup Hyg 42, 377-90.

21) Maidment SC (1998) Occupational hygiene considerations in the development of a structured approach to select chemical control strategies. Ann Occup Hyg 42, 391-400.

22) Paik S, Zalk D, Swuste P (2008) Application of a pilot control banding tool for risk level assessment and control of nanoparticle exposures. Ann Occup Hyg 52, $419-28$.

23) Swuste P (2007) Qualitative methods for occupational risk prevention strategies in safety, or control banding - Safety. Safety Sci Monitor 11, 1-7.

24) Zalk DM, Spee T, Gillan M, Lentz TJ, Garrod A, Evans P, Swuste P (2010) A risk management toolbox for hazards in the construction industry. Ann Occup Hyg (in press).

25) Hogue C (2007) National Research Council blasts risk guidelines. Chem \& Eng News January 12, 2007. http://pubs.acs.org/cen/news/85/i03/8503nrc.html. Accessed July 20, 2009.

26) Foster KR, Vecchia P, Repacholi MH (2000) Risk management: science and the precautionary principle. Science 288, 979-81.

27) Coyle IR, Sleeman SD, Adams N (1995) Safety climate. $\mathrm{J}$ of Safety Res 26, 247-54.

28) Rundmo $T$ (1996) Associations between risk perception and safety. Safety Sci 24, 197-209.

29) Guldenmund FW (2000) The nature of safety culture: a review of theory and research. Safety Sci 34, 215-57.

30) Moir S (2005) Ideological influences on participatory research in occupational health and safety: a review of the literature. New Solut 15, 15-28.

31) Zalk DM (2002) Participatory occupational hygiene; a path to practical solutions. Asian-Pacific Newsletter 9, 51.

32) Kogi K (2006) Advances in participatory occupational health aimed at good practices in small enterprises and the informal sector. Ind Health 44, 31-4.

33) Rosenberg BJ, Barbeau EM, Moure-Eraso R, Levenstein C (2001) The work environment impact assessment: a methodologic framework for evaluating health-based interventions. Am J Ind Med 39, 218-26.

34) Ackoff RL (1999) Re-creating the corporation, a design of organizations for the 21st Century, 63-80, Oxford University Press, New York.

35) Zalk DM (2000) Exposure assessment techniques to reduce occupational uptake of asbestos and lead for maintenance activities. IOHA Cairns 2000 Abstract 60, Cairns, Australia. http://nla.gov.au/nla.cat-vn2019109. Accessed July 20, 2009.

36) Oberta AF, Fischer KE (2000) Negative exposure assessments for asbestos floor tile work practices. Within advances in environmental measurement methods for asbestos, Beard ME and Rook HL (Eds.), 193-208, ASTM International, West Conshohocken.

37) Lee EG, Harper M, Bowen RB, Slaven J (2009) Evaluation of COSHH Essentials: methylene chloride, isopropanol, and acetone exposures. Ann Occup Hyg, Advance Access, mep023 12 May.

38) Bracker AL, Morse TF, Simcox NJ (2009) Training health and safety committees to use control banding: lessons learned and opportunities for the United States. J Occup Env Hyg 6, 307-14.

39) Zalk DM, Paik SY, Swuste P (2009) Evaluating the Control Banding Nanotool: a qualitative risk assessment method for controlling nanoparticle exposures. J Nanopart Res 11, 1685-704. 